ISAHP 1999, Kobe, Japan, August 12 - 14, 1999

\title{
CLARIFYING THE BUSINESS STRATEGY OF THE INDONESIAN PAWNING STATE COMPANY: COMBINING AHP AND BALANCED SCORECARD
}

\author{
Kirti Peniwati and Nani Koespriani \\ PPM Graduate School of Management \\ Jl. Menteng Raya 9, Jakarta 10340, Indonesia \\ kirti@cabi.net.id/nkp@indo.net.id
}

\begin{abstract}
The most source of failure in implementing business strategy of company is because of the inability to translate business strategy to strategic actions. Translating strategic objectives into strategic actions is very important since it will determine the strategy implementation success. Balance Scorecard has been proven as an effective method to translate the strategic objectives into strategic actions. It shows the causeeffect relationship among many aspects in the company, as well as relationship between strategic objectives, performance criteria and strategic actions. Nevertheless, this cause-effect relationship could even more be clarified and sharpened using the AHP. Many strategic actions that could not be derived from BSC method, could be derived using AHP resulting in clearer strategic actions that have to be taken by many units of the company.
\end{abstract}

\section{Introduction}

It has been recognized that AHP enhances the application of Balanced Scorecard. Not only that AHP clarifies more of cause-effect relationships between organization's objectives from the Balance Scorecard's four different perspectives, but it also enables an organization ensures prioritizing strategic actions based on the relative importance of the business strategies. The purpose of this paper is to show how combining the AHP and Balanced Scorecard could improve the quality of strategy formulation in the context of the Indonesian Pawning State Company.

The model developed here is based on, but not necessarily consistent with, what has been developed by Eduard Eliza Siahaya [1998]. It is important to note that, while the project was carried out with the permission of the management of the Indonesian Pawning State Company, the content of this paper is not necessarily in agreement with the actual business intention and the activities of the company.

\section{The Pawning State Company.}

The Pawning State Company is, by government regulation, a monopoly legal provider of pawning service in Indonesia. Its status has been developed gradually from a government service office when a Dutch pawning bank changed status in 1901, into a 
state company with more business orientation and less dependence on the government financial support. However, its mission is still more of a public service than a business entity. It has targeted its market to the mid-lower class community; to prevent them from being the victims of profiteers who would take advantage of their desperation of short-term financial needs by demanding a very high interest. It has been realized that the company should position itself more as a business entity to be more effective in the current environment.

\section{TheDevelopment of Strategies and the Balanced Scorecard Model}

Siahaya [1998] first brought forward his recommendation for the company to reformulate its vision and mission to address the expectation of its stakeholders. He then carried out SWOT analysis and developed eight strategies, guided by the recommended vision and mission. He used AHP to rate the strategies through a costsbenefits-opportunities-risks (CBOR) analysis, and obtained the following ratio: Optimize service (5.95), Develop IT system (3.61), Improve image (3.61), Capital Restructuring (2.19), Company Restructuring (0.77), Expand to East Indonesia (0.29), and Change Status (0.11).

\section{The Original Balanced Scorecard}

Siahaya developed his Balanced Scorecard by formulating a set of strategic objectives for each perspective (financial, customer, internal business process, and growth/learning). For each objective, he identified core outcomes; performance drivers and strategic actions. His result is as follows:

\begin{tabular}{|c|c|c|c|c|}
\hline No. & $\begin{array}{c}\text { Strategic } \\
\text { Objectives }\end{array}$ & Core Outcomes & $\begin{array}{c}\text { Performance } \\
\text { Drivers }\end{array}$ & $\begin{array}{l}\text { Strategic } \\
\text { Initiatives }\end{array}$ \\
\hline $\begin{array}{l}\text { F1. } \\
\text { F2. }\end{array}$ & $\begin{array}{l}\text { Einancial } \\
\text { Meet Government } \\
\text { Criteria } \\
\text { Mix of income }\end{array}$ & $\begin{array}{l}\text { Company Rating } \\
\text { Income structure }\end{array}$ & $\begin{array}{l}\text { Rentability, Solvability, } \\
\text { Liquidity } \\
\text { Profit Margin, } \\
\text { Operational Ratio, } \\
\text { Interest Vs Cost of Fund. }\end{array}$ & $\begin{array}{l}\text { Conduct profitable } \\
\text { business based on } \\
\text { mission and vision. } \\
\text { Capital } \\
\text { restructuring }\end{array}$ \\
\hline $\begin{array}{l}\text { C1. } \\
\text { C2. } \\
\text { c3. }\end{array}$ & $\begin{array}{l}\text { Customer } \\
\text { Customer } \\
\text { Satisfaction }\end{array}$ & $\begin{array}{l}\text { Customer retention } \\
\text { Customer Claims } \\
\text { Customer } \\
\text { Acquisition } \\
\text { P3 ratio }\end{array}$ & $\begin{array}{l}\text { Quality of service } \\
\text { Service products } \\
\text { \# customer advised }\end{array}$ & $\begin{array}{l}\text { Improve operations } \\
\text { Customer } \\
\text { stratification } \\
\text { Conduct advisory } \\
\text { service }\end{array}$ \\
\hline
\end{tabular}




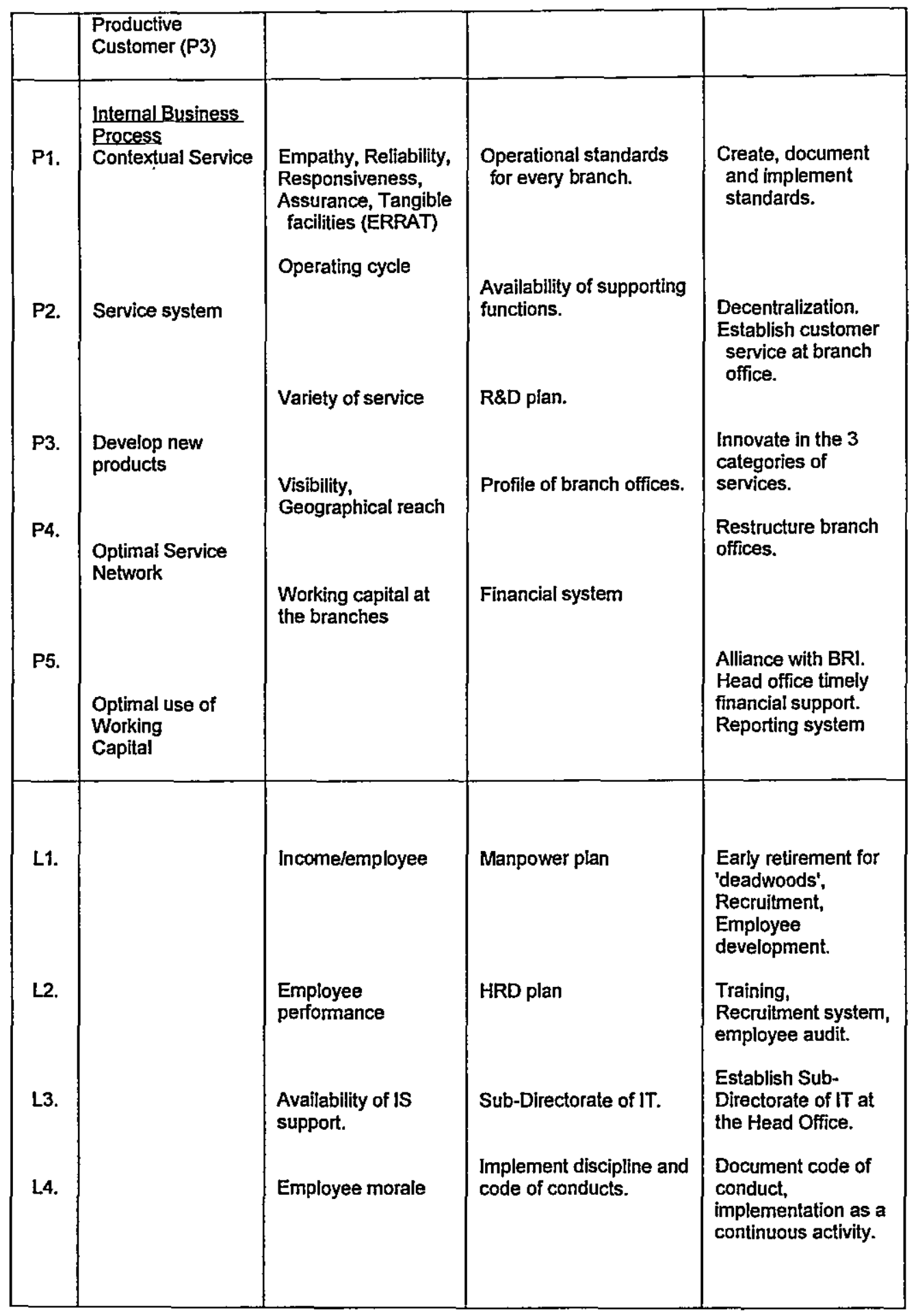


The Need for AHP to Improve the Results of the Balanced Scorecard.

Siahaya created a diagram to indicate cause-effect relationships between core outcomes and performance drivers both within and across the four perspectives. AHP can be used to describe such complex cause-effect relationships, along with other relationships that may exist between strategic objectives and strategic initiatives across different perspectives. Moreover, the systematic process of the AHP forces the user to be more specific in formulating the content of his Balanced Scorecard, which improves the quality of the plan.

- A strategic initiative for one perspective could be a strategic objective for another perspective.

- There may be more than one level cause-effect chain in one perspective, which is difficult to show effectively in a Balanced Scorecard format.

\section{Creating an AHP Structure with Balanced Scorecard Approach}

An AHP structure with Balanced Scorecard approach can be developed through same steps in original BSC combined with steps in AHP :

- Level 0 is the goals, which are Customer Satisfaction and Profitability

- Level 1 is the strategic objectives, which have to be performed in order to achieve the goals

- Level 2 is the core outcomes, the generic results which expressed the strategic objectives

- Level 3 is the performance drivers, the specific results of core outcomes

- Level 4 is the strategic initiatives, the actions that have to be taken in order to perform the performance drivers. 
The complete AHP structure is as follow:

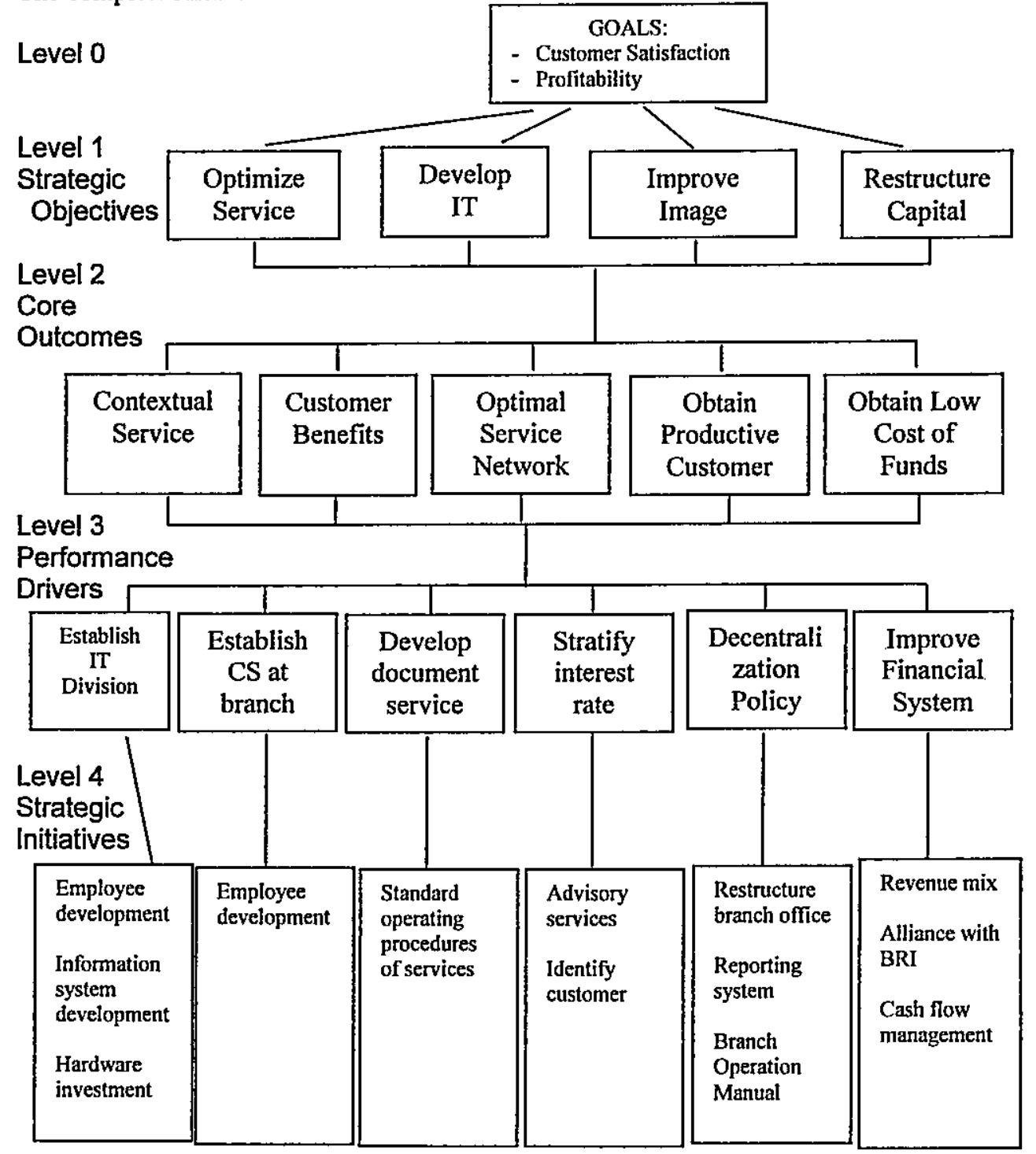

Using a systematic approach of AHP, some strategic initiatives have been derived from the structure, which is not shown in original BSC approach.

\section{Revised Balanced Scorecard for the Indonesian Pawning State Company}

The revised Balanced Scorecard for the Indonesian Pawning State Company concerning Customer Satisfaction and Profitability as strategic goals described in the table below : 


\begin{tabular}{|c|c|c|c|}
\hline $\begin{array}{l}\text { STRATEGIC } \\
\text { OBJECTIVES } \\
\end{array}$ & CORE OUTCOMES & $\begin{array}{c}\text { PERFORMANCE } \\
\text { DRIVERS }\end{array}$ & $\begin{array}{l}\text { STRATEGIC } \\
\text { INITIATIVES } \\
\end{array}$ \\
\hline $\begin{array}{l}\text { INTERNAL } \\
\text { BUSINESS } \\
\text { PROCESS } \\
\text { Optimize service }\end{array}$ & $\begin{array}{l}\text { Contextual service } \\
\text { Customer benefits } \\
\text { Optimal service network } \\
\text { Obtain productive } \\
\quad \text { customer }\end{array}$ & $\begin{array}{l}\text { Establish CS at branch } \\
\text { Develop document } \\
\text { service standard } \\
\text { Decentralization policy }\end{array}$ & $\begin{array}{l}\text { CS SOP at branch } \\
\text { Branch organization } \\
\text { restructuring } \\
\text { SOP of services } \\
\text { Restructure branch office } \\
\text { Reporting System } \\
\text { Branch operation manual }\end{array}$ \\
\hline $\begin{array}{l}\text { LEARNING \& } \\
\text { GROWTH } \\
\text { Develop IT }\end{array}$ & $\begin{array}{l}\text { Contextual service } \\
\text { Customer benefits } \\
\text { Optimal service network } \\
\text { Obtain productive }\end{array}$ & $\begin{array}{l}\text { Establish IT division } \\
\text { Develop document } \\
\text { service standard }\end{array}$ & $\begin{array}{l}\text { Employee development } \\
\text { IS development } \\
\text { Hardware investment } \\
\text { Employee discipline }\end{array}$ \\
\hline $\begin{array}{l}\text { CUSTOMER } \\
\text { Improve image }\end{array}$ & $\begin{array}{l}\text { Contextual service } \\
\text { Customer benefits } \\
\text { Optimal service network } \\
\text { Obtain productive } \\
\text { customer } \\
\text { Obtain low cost of funds }\end{array}$ & Stratify Interest Rate & $\begin{array}{l}\text { Advisory services } \\
\text { Customer assessment } \\
\text { Database development }\end{array}$ \\
\hline $\begin{array}{l}\text { FINANCIAL } \\
\text { Restructure capital }\end{array}$ & $\begin{array}{l}\text { Obtain productive } \\
\text { customer } \\
\text { Obtain low cost of funds }\end{array}$ & $\begin{array}{l}\text { Improve Financial } \\
\text { System }\end{array}$ & $\begin{array}{l}\text { Revenue mix } \\
\text { Alliance with BRI } \\
\text { CFNC management }\end{array}$ \\
\hline
\end{tabular}

The AHP structure process result in a set of sharper and clearer strategic actions. Some actions could not even be derived from the original BSC model. The cause and effect relationship between strategic objectives, core outcomes, performance drivers and strategic actions can be formulated with more obvious.

The strategic actions derived from performance drivers using AHP structure will be best to implement by prioritizing the strategic actions. Pair wise comparison of all strategic actions shows that Customer assessment is the most urgent action that the company should take, and the employee discipline is the least priority, concerning the goal: Customer satisfaction and profitability.

\section{Conclusion}

Translating strategy into action would be best carried out using the combination of Balanced Scorecard and AHP:

1. Develop alternative strategies and select the best strategies using the AHP's CBOR analysis.

2. Construct a Balanced Scorecard

3. Refine BSC using AHP structure

4. Redesign BSC based on AHP result

5. Reprioritize the strategic actions. 


\section{Reference}

Kaplan, R. S. and D. P. Norton, (1996). The Balanced Scorecard: translating strategy into action, Harvard business School Press, Boston, Massachusetts.

Siahaya, E. E., (1998). Reorientasi Visi dan Strategi Bisnis Perum Pegadaian di $A b a d 21$, an unpublished final project report, PPM Graduate School of Management, Jakarta.

Saaty, TL (1990) The Analytic Hierarchy Process: Planning, Priority Setting, Resource Allocation. RWS Publication, Pittsburgh, PA. 